\title{
Gonadotropin-releasing hormone increased pregnancy risk in suckled beef cows not detected in estrus and subjected to a split-time artificial insemination program ${ }^{1,2}$
}

\author{
S. L. Hill,* D. M. Grieger,* K. C. Olson,* J. R. Jaeger,* \\ C. R. Dahlen, $\uparrow$ M. R. Crosswhite,$\uparrow$ N. Negrin Pereira,$\dagger$ S. R. Underdahl, $\uparrow$

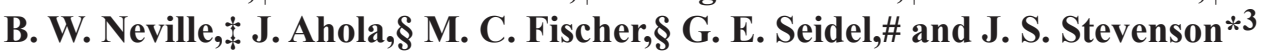 \\ *Department of Animal Sciences and Industry, Kansas State University, Manhattan 66506-0201; \\ $\dagger$ Department of Animal Sciences, North Dakota State University, Fargo 58105; †Central Grasslands \\ Research Extension Center, Streeter, ND 58483; §Department of Animal Sciences, and \#Department of Biomedical \\ Sciences, Colorado State University, Fort Collins 80523
}

\begin{abstract}
We hypothesized that GnRH would increase pregnancy risk (PR) in a split-time AI program for cows in which estrus was not detected. A total of 1,236 suckled beef cows at 12 locations in 3 states (Colorado, Kansas, and North Dakota) were enrolled. Before applying the fixed-time AI program, BCS was assessed. Cows were treated on $\mathrm{d}-7$ with a progesterone insert concurrent with $100 \mu \mathrm{g} \mathrm{GnRH}$ and on $\mathrm{d} 0$ with $25 \mathrm{mg} \mathrm{PGF}{ }_{2 \alpha}$ plus removal of the insert. Estrus-detection patches were affixed to cows at insert removal. Estrus was defined to have occurred when an estrus-detection patch was $>50 \%$ colored (activated). Cows in estrus by $65 \mathrm{~h}(n=758 ; 61.3 \%$ of all cows $)$ were randomly allocated to 2 treatments: 1) $100 \mu \mathrm{g}$ $\mathrm{GnRH}$ and early $+\mathrm{GnRH}(\mathrm{E}+\mathrm{G} ; n=373)$ or 2$) \mathrm{AI}$ only at $65 \mathrm{~h}$ (early - no GnRH [E-G]; $n=385$ ). The remaining cows were randomly allocated to 2 treatments: 1 ) $5(\mathrm{~L}+\mathrm{G} ; n=252)$ or 2 ) AI only at $84 \mathrm{~h}$ (late no $\mathrm{GnRH}$ $[\mathrm{L}-\mathrm{G}] ; n=226)$. Pregnancy was determined $35 \mathrm{~d}$ after
\end{abstract}

AI via transrectal ultrasound. Pregnancy risk did not differ $(P=0.68)$ between $\mathrm{E}+\mathrm{G}$ and $\mathrm{E}-\mathrm{G}$ cows $(61.9$ vs. $60.4 \%$, respectively). Conversely, for cows inseminated at $84 \mathrm{~h}, \mathrm{PR}$ was greater $(P=0.01)$ in cows that received $\mathrm{GnRH}(\mathrm{L}+\mathrm{G})$ compared with their herd mates not receiving GnRH (L- G; 41.7 vs. 30.8\%, respectively). Of those cows not detected in estrus by 65 h, $42.1 \%$ were detected by $84 \mathrm{~h}$, for a total expression of estrus by all cows of $77.6 \%$. Administration of $\mathrm{GnRH}$ increased $(P<0.01) \mathrm{PR}$ in cows not detected in estrus by $84 \mathrm{~h}$ $(+\mathrm{GnRH}=33.4 \%[n=146]$ vs. no $\mathrm{GnRH}=15.0 \%[n=$ 128]) but had no effect in cows expressing estrus by $84 \mathrm{~h}(+\mathrm{GnRH}=65.3 \%[n=103]$ vs. no $\mathrm{GnRH}=61.7 \%$ $[n=97])$. Neither estrus expression by 65 or $84 \mathrm{~h}$ nor PR was influenced by BCS, parity, or days postpartum at AI. Cows had greater PR when they had been detected in estrus before AI, and PR was improved by administration of GnRH at $65 \mathrm{~h}$ after insert removal in cows that were not detected in estrus and inseminated at $84 \mathrm{~h}$.

Key words: beef cattle, estrus detection, gonadotropin-releasing hormone, timed artificial insemination

\section{INTRODUCTION}

\footnotetext{
${ }^{1}$ We gratefully acknowledge the donations of Factrel, Lutalyse, and CIDR inserts from Roger Saltman, Zoetis, Florham Park, NJ, and Boyd Dingus, Estrotect, Spring Valley, WI, for supplying the estrus-detection patches. We acknowledge Wenjing Fausnett for analyzing progesterone concentrations in blood samples.

${ }^{2}$ Contribution number 16-303-J from the Kansas Agricultural Experiment Station, Manhattan, KS.

${ }^{3}$ Corresponding author: jss@ksu.edu

Received April 27, 2016.

Accepted June 24, 2016.
}

Estrus-synchronization programs allow insemination of all females in a herd at one fixed time on the first day of the breeding season. Inseminating cows after they have expressed estrus increases pregnancy risk (PR) compared with cows that do not display estrus in a timed AI (TAI) program (Richardson et al., 2016). Identification of estrus status can be facilitated by using estrus-detection patches. Varying AI timing according to estrus status has increased PR in some (Markwood et al., 2014; Thomas et al., 2014a; Hill et al., 2016) but not 
all studies (Thomas et al., 2014b). Reducing the number of injections in a TAI program decreases labor requirements, stress on cows, and overall cost of the program. Previous studies have demonstrated that PR is not compromised in cows displaying estrus when the GnRH injection concurrent with AI is eliminated (Perry and Perry, 2009). A split-time AI program decreases the time between estrus expression and insemination compared with a single fixed-time AI when the first AI occurs before the recommended standard 60- to 66-h fixed time (Johnson et al., 2011). Delaying AI results in approximately 50\% more cows displaying estrus when compared with a single insemination time (Hill et al., 2016). Eliminating the GnRH injection at AI for cows displaying estrus in a split TAI program can reduce the number of GnRH injections required and the program cost. The objective of this study was to test the hypothesis that GnRH injection concurrent with split TAI program improves PR only in cows not displaying estrus.

\section{MATERIALS AND METHODS}

\section{Experimental Design}

The Kansas State University Animal Care and Use Committee approved all experimental procedures (protocol number 3392). A total of 1,236 mixed-parity suckled beef cows at 12 locations in 3 states (Colorado, Kansas, and North Dakota) were enrolled in the experiment in 2015. Body condition scores $(1=$ thin and $9=$ obese; Bellows et al., 1982) were assigned $(\mathrm{d}-17)$ before the start of the TAI program by a trained evaluator (Fig. 1). Characteristics of suckled beef cows enrolled by location including breed, parity, days postpartum at split TAI, and BCS at the onset of the synchronization program are summarized (Table 1). All cows were injected intramuscularly with $100 \mu \mathrm{g}$ GnRH (2 mL Factrel; Zoetis Inc., Florham Park, NJ) 7 d before $25 \mathrm{mg} \mathrm{PGF}_{2 \alpha}$ on d 0 (5 mL Lutalyse; Zoetis Inc.). A new progesterone-impregnated controlled internal drug release (CIDR) insert (Zoetis Inc.) containing $1.38 \mathrm{~g}$ progesterone was placed intravaginally at the time of the GnRH injection $(\mathrm{d}-7)$. Progesterone inserts were removed and $\mathrm{PGF}_{2 \alpha}$ was injected at $1700 \mathrm{~h}$ on $\mathrm{d} 0$ to allow for AI to begin $65 \mathrm{~h}$ later at $1000 \mathrm{~h}$. The 84-h time was selected to begin the second AI time as early as daylight would allow $(0700 \mathrm{~h})$ and to allow insemination of cows approximately 5 to $13 \mathrm{~h}$ before ovulation induced by GnRH 19 h earlier. Ovulation occurs between 24 and $32 \mathrm{~h}$ after exogenous $\mathrm{GnRH}$ in cattle (Wiltbank and Pursley, 2014).

On d 0, concurrent with CIDR insert removal, estrus-detection patches (Estrotect, Spring Valley, WI) were affixed to the tail head of all cows according to the

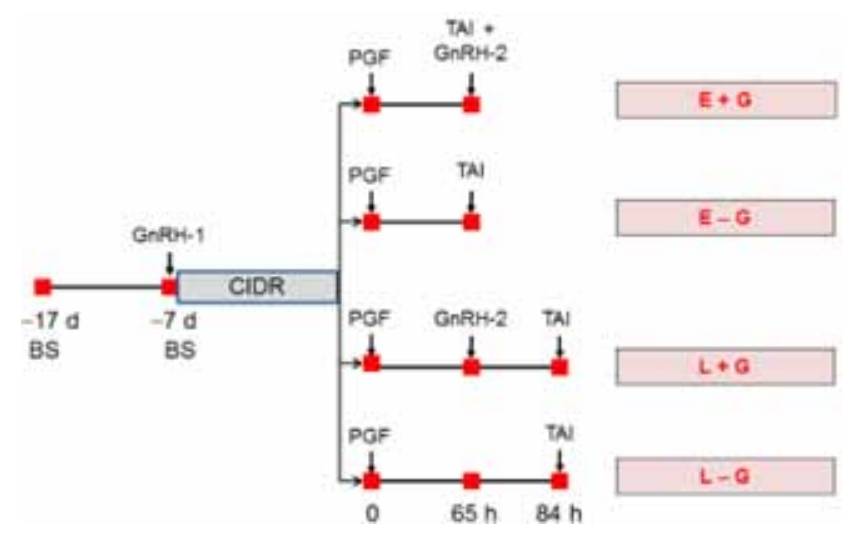

Figure 1. Experimental design of treatments. All cows $(n=1,236)$ received intramuscularly $100 \mu \mathrm{g} \mathrm{GRH}(\mathrm{GnRH}-1)$ and a controlled internal drug release (CIDR) insert containing $1.38 \mathrm{~g}$ of progesterone followed in $7 \mathrm{~d}$ by $25 \mathrm{mg} \mathrm{PGF}$ PG $_{2 \alpha}$ (PGF) and CIDR removal (d 0). Cows with patches $>50 \%$ activated were defined to be in estrus and treatment assignments were made at $65 \mathrm{~h}$. The $100 \mu \mathrm{g} \mathrm{GnRH}$ and early AI at $65 \mathrm{~h}(\mathrm{E}+\mathrm{G})$ cows $(n=373)$ received $100 \mu \mathrm{g} \mathrm{GnRH}(\mathrm{GnRH}-2)$ and insemination at $65 \mathrm{~h}$. The AI only at $65 \mathrm{~h}(\mathrm{E}-\mathrm{G})$ cows $(n=385)$ received no GnRH and were inseminated at $65 \mathrm{~h}$. The $100 \mu \mathrm{g}$ GnRH at $65 \mathrm{~h}$ and late $\mathrm{AI}$ at $84 \mathrm{~h}(\mathrm{~L}+\mathrm{G})$ cows $(n=252)$ received GnRH-2 at $65 \mathrm{~h}$ and were inseminated at $84 \mathrm{~h}$. The AI only at $84 \mathrm{~h}(\mathrm{~L}-\mathrm{G})$ cows $(n=226)$ received no GnRH and were inseminated at $84 \mathrm{~h}$. Blood samples (BS) were collected on $\mathrm{d}-17$ and -7 from a subset of cows $(n=$ 427) at 8 of 12 locations. TAI $=$ timed AI.

manufacturer's recommendation. Patches were evaluated at $65 \mathrm{~h}$ after CIDR insert removal, and estrus was defined to have occurred when an estrus-detection patch was $>50 \%$ colored (activated). Cows with activated patches were assigned by random chute order to either receive $100 \mu \mathrm{g} \mathrm{GnRH}$ and early $\mathrm{AI}$ at $65 \mathrm{~h}(\mathbf{E}+\mathbf{G})$ or $\mathrm{AI}$ only at $65 \mathrm{~h}(\mathbf{E}-\mathbf{G})$. Remaining nonestrus cows received either $100 \mu \mathrm{g} \mathrm{GnRH}$ at $65 \mathrm{~h}$ and late $\mathrm{AI}$ at $84 \mathrm{~h}(\mathbf{L}+\mathbf{G})$ or AI only at $84 \mathrm{~h}(\mathbf{L}-\mathbf{G})$. An additional evaluation of patch activation status was also conducted at $84 \mathrm{~h}$ to determine if activation had occurred between 65 and $84 \mathrm{~h}$.

\section{Pregnancy Diagnosis}

Cows were either observed for estrus and reinseminated on subsequent estrus or were exposed to cleanup bulls beginning 10 to $12 \mathrm{~d}$ after split TAI. At $35 \mathrm{~d}$ after split TAI, pregnancy risk (PR) was confirmed by transrectal ultrasonography (Aloka $500 \mathrm{~V}, 5 \mathrm{MHz}$ transrectal transducer, Wallingford, CT). A positive pregnancy outcome required the presence of an embryo with a visible heart beat. In rare exceptions, when an embryo was not observed, a corpus luteum and uterine fluid consistent with a d-35 pregnancy was evidence for a positive diagnosis. A final pregnancy diagnosis was determined via transrectal ultrasonography or palpation per rectum no sooner than $35 \mathrm{~d}$ after the end of the breeding season (range of 35 to $42 \mathrm{~d}$ ). Pregnancy loss was defined as those cows pregnant $35 \mathrm{~d}$ after split TAI but not at the appropriate stage of pregnancy at the time of the final pregnancy diagnosis. 
Table 1. Selected characteristics of suckled beef cows enrolled in the experiment

\begin{tabular}{|c|c|c|c|c|c|c|c|}
\hline Location $^{1}$ & Breed $^{2}$ & $n$ & 2 yr old, $\%$ & Days postpartum at $\mathrm{AI}^{3}$ & $\mathrm{BCS}^{3}$ & Estrus cycle status, ${ }^{4} \%$ & Pregnancy risk, ${ }^{5} \%$ \\
\hline$\overline{\mathrm{CO}-1}$ & $\mathrm{~A}$ & 333 & 26 & $83 \pm 1.0$ & $4.6 \pm 0.02$ & -6 & 58.9 \\
\hline $\mathrm{CO}-2$ & A & 80 & 23 & $81 \pm 1.9$ & $5.5 \pm 0.08$ & -6 & 68.8 \\
\hline KS-1 & $\mathrm{H}$ & 39 & 28 & $78 \pm 2.9$ & $5.6 \pm 0.08$ & 33 & 66.7 \\
\hline $\mathrm{KS}-2$ & $\mathrm{~A} \times \mathrm{H}$ & 40 & 25 & $82 \pm 2.6$ & $5.7 \pm 0.10$ & 53 & 45.0 \\
\hline KS-3 & $\mathrm{A} \times \mathrm{H}$ & 77 & 31 & $84 \pm 1.7$ & $5.4 \pm 0.07$ & 61 & 49.4 \\
\hline KS-4 & $\mathrm{A} \times \mathrm{H}$ & 61 & 26 & $83 \pm 1.8$ & $5.4 \pm 0.09$ & 49 & 55.7 \\
\hline KS-5 & $\mathrm{A} \times \mathrm{H}$ & 64 & 86 & $78 \pm 2.6$ & $5.5 \pm 0.08$ & 6 & 23.4 \\
\hline KS-6 & $\mathrm{A} \times \mathrm{H}$ & 98 & 0 & $69 \pm 1.8$ & $5.7 \pm 0.06$ & 18 & 46.9 \\
\hline KS-7 & $\mathrm{A} \times \mathrm{H}$ & 29 & 0 & $49 \pm 3.8$ & $5.8 \pm 0.07$ & 14 & 51.7 \\
\hline KS-8 & $\mathrm{A} \times \mathrm{H}$ & 19 & 0 & $69 \pm 4.2$ & $5.3 \pm 0.18$ & 5 & 21.1 \\
\hline ND-1 & $\mathrm{A} \times \mathrm{H}$ & 190 & 0 & $72 \pm 1.4$ & $4.4 \pm 0.04$ & -6 & 68.9 \\
\hline ND-2 & $\mathrm{A} \times \mathrm{H}$ & 206 & 32 & $83 \pm 1.2$ & $4.3 \pm 0.04$ & $-^{6}$ & 62.6 \\
\hline
\end{tabular}

${ }^{1}$ Cows at 12 locations in 3 states were enrolled. $\mathrm{CO}=$ Colorado; $\mathrm{KS}=$ Kansas; $\mathrm{ND}=$ North Dakota.

${ }^{2} \mathrm{~A}=$ Angus and $\mathrm{H}=$ Hereford.

${ }^{3}$ Mean \pm SE.

${ }^{4}$ Based on progesterone concentrations measured in 2 blood samples collected $10 \mathrm{~d}$ apart before the onset of the experimental protocol in 427 cows (cut point for determining a functional corpus luteum was $\geq 1 \mathrm{ng} / \mathrm{mL}$ ).

${ }^{5}$ Assessed at $35 \mathrm{~d}$ after AI.

${ }^{6}$ Blood samples were not collected to assess estrus cycle status.

\section{Estrus-Cycle Status}

Blood samples were collected via puncture of a caudal blood vessel from cows $(n=427)$ at 8 of the 12 locations on $\mathrm{d}-17$ and -7 . Concentrations of progesterone in blood serum were measured in all samples by direct quantitative (nonextracted) RIA using ImmuChem Double Antibody progesterone ${ }^{125} \mathrm{I}$ kits (catalog number 07-170105; MP Biomedicals LLC, Orangeburg, NY) and validated for bovine serum. The radioligand was ${ }^{125} \mathrm{I}$-labeled progesterone $(1,500$ to $2,000 \mu \mathrm{Ci} / \mu \mathrm{g})$. The antiprogesterone antibody was generated in rabbits using $11 \alpha$-hydroxyprogesterone- $11 \alpha$-hemisuccinate-human serum albumin as the antigen. Kit standards $(0.2,0.5,2.0$, $5.0,10.0,25.0$, and $50.0 \mathrm{ng} / \mathrm{mL}$ ), to which we added 2 more standards $(0.05$ and $0.1 \mathrm{ng} / \mathrm{mL})$, unknowns, and assay pools were added ( $100 \mu \mathrm{L}$ each) in duplicate to 12 - by 75 -mm plastic conical tubes. Next, $500 \mu \mathrm{L}$ of antiprogesterone antibody and $200 \mu \mathrm{L}$ of ${ }^{125}$ I-labeled progesterone were added to each tube, vortexed for $5 \mathrm{~s}$, and incubated for $1 \mathrm{~h}$ in a water bath at $37^{\circ} \mathrm{C}$. Next, $500 \mu \mathrm{L}$ of a precipitant solution (second antibody) were added to all tubes and thoroughly vortexed for $10 \mathrm{~s}$ before centrifuging at $5^{\circ} \mathrm{C}$ for $30 \mathrm{~min}$ at $5,000 \times \mathrm{g}$. Tubes were then decanted and blotted on paper towels, and the radioactivity of each tube was quantified for $1 \mathrm{~min}$ in a $\gamma$ counter. Recovery of added progesterone in triplicate to $100 \mu \mathrm{L}$ of 4 different bovine serum samples $(0.39,1.38,3.67$, and $13.72 \mathrm{ng} /$ $\mathrm{mL}$ ) averaged $101.5 \%$. Parallelism was demonstrated by assaying 50-, 75- and 100- $\mu \mathrm{L}$ aliquots of bovine serum at 2 different concentrations in quadruplicate. Recovery of added progesterone averaged 105.5\%. Duplicate unknowns that failed to replicate within $10 \%$ were reassayed.
Intra-assay $\mathrm{CV}$ for progesterone was 5.6\%. Interassay CV for the low and high pool was 11.9 and $9.3 \%$, respectively. Assay sensitivity was $53.4 \pm 14.4 \mathrm{pg} / \mathrm{mL}$.

Cows with a serum progesterone concentration $\geq$ $1.0 \mathrm{ng} / \mathrm{mL}$ at either $\mathrm{d}-17$ or -7 were defined to have resumed estrous cycles (Ireland et al., 1980). All other sampled cows with concentrations of progesterone < $1.0 \mathrm{ng} / \mathrm{mL}$ were considered to have been anestrous at the onset of the ovulation synchronization program (Table 1).

\section{Statistical Analyses}

The median values of the continuous variables BCS $(<5$ vs. $\geq 5)$ and days postpartum $(\leq 82$ vs. $>82$ d) were used to create corresponding binomial variables. Each of the dependent variables (estrus cycle status, estrus expression at 3 time intervals [by $65 \mathrm{~h}, 65$ through $84 \mathrm{~h}$, and by $84 \mathrm{~h}$ ], PR, final PR, and pregnancy loss) was regressed on the independent variables in the LOGISTIC procedure (SAS Inst. Inc., Cary, NC). A final model was produced using the stepwise selection method with a $P$-value $<0.30$ for initial inclusion and $P<0.15$ for retention in the model. The independent fixed variables - BCS, days postpartum, and parity (primiparous vs. multiparous) - and all interactions of these variables were initially included in the selection for estrus cycle status. A final model produced by backward stepwise selection of independent variables entered or retained in the model was based on a Wald statistic $(P<0.10)$.

A similar selection procedure was performed with the remaining outcome variables with the following inclusions: estrus cycle status was added as an independent variable in the remaining models, total estrus 
expression was added to the models analyzing PR and pregnancy loss, and treatment was added to all models. The list of variables measured and the factors included in the final model are summarized in Table 2.

The GLIMMIX procedure (method = laplace, ilink = logit, and dist = binomial solution oddsratio) in SAS was used to analyze the binomial outcome variables. Differences of means calculated using unequal sample sizes were adjusted using the Bonferroni adjustment. An additional GLIMMIX model with PR as the dependent variable was constructed to examine the interaction of GnRH injection and estrus expression for the cows inseminated at $84 \mathrm{~h}$. The location of each herd was included in all models as a random variable. Differences were considered significant at $P \leq 0.05$.

\section{RESULTS}

\section{Pregnancy Risk}

Cows detected in estrus and inseminated at $65 \mathrm{~h}$ had greater PR than the cows inseminated at $84 \mathrm{~h}$ regardless of GnRH treatment (Fig. 2). Pregnancy risk was not improved $(P=0.68)$ by administration of GnRH in cows that were in estrus by $65 \mathrm{~h}$ (61.9 and $60.4 \%$ for $\mathrm{E}+\mathrm{G}$ and $\mathrm{E}-\mathrm{G}$, respectively). For cows inseminated at $84 \mathrm{~h}, \mathrm{PR}$ was greater $(P=0.001)$ in cows that received $\mathrm{GnRH}$ at $65 \mathrm{~h}(\mathrm{~L}+\mathrm{G})$ compared with their herd mates not receiving GnRH at $65 \mathrm{~h}$ (41.7 and $30.8 \%$ for $\mathrm{L}+\mathrm{G}$ and $\mathrm{L}-\mathrm{G}$, respectively).

Four cows were eliminated from the analysis of PR because patch data were not available at $84 \mathrm{~h}$. Administration of $\mathrm{GnRH}$ at $65 \mathrm{~h}$ increased $(P<0.01)$ $\mathrm{PR}$ in cows not detected in estrus by $84 \mathrm{~h}$ (Fig. 3). In contrast, administration of GnRH did not impact PR $(P=0.60)$ in cows expressing estrus during the interval from 65 to $84 \mathrm{~h}$. Pregnancy risk for cows inseminated at either time was not affected $(P \geq 0.10)$ by BCS, parity, or days postpartum at AI. Final PR assessed at least $35 \mathrm{~d}$ after the end of the breeding season for $\mathrm{E}+\mathrm{G}, \mathrm{E}-\mathrm{G}, \mathrm{L}+\mathrm{G}$, and $\mathrm{L}-\mathrm{G}$ cows were 87.4, 89.0, 84.5, and 78\%, respectively. Final PR of $\mathrm{L}-\mathrm{G}$ cows differed from $\mathrm{E}+\mathrm{G}(P=0.02)$ and $\mathrm{E}-\mathrm{G}$ cows $(P$ $=0.004)$. Body condition score did not affect final PR. An interaction $(P=0.05)$ was detected between days postpartum and parity when considering the final PR. Primiparous cows that were $\leq 82 \mathrm{~d}$ postpartum had a lesser $(P=0.003)$ final PR than primiparous cows $>82$ d (70.9 vs. $87.6 \%$, respectively). Final PR of primiparous cows $\leq 82 \mathrm{~d}$ postpartum also differed $(P=0.01)$ from that of multiparous cows $\leq 82 \mathrm{~d}$ and multiparous cows $>82 \mathrm{~d}$ ( 87.8 and $89.7 \%$, respectively).

Pregnancy loss $(1.3 \%)$ between $35 \mathrm{~d}$ after TAI and final pregnancy status after the end of the breeding
Table 2. Composition of statistical model selections

\begin{tabular}{|c|c|c|}
\hline Dependent variable & Independent variable & Interactions \\
\hline Estrus cycling status & Days $^{1}$ and parity & None $^{2}$ \\
\hline Estrus by $65 \mathrm{~h}$ & None $^{3}$ & None $^{2}$ \\
\hline Estrus from 65 to $84 \mathrm{~h}$ & None $^{3}$ & None $^{2}$ \\
\hline Estrus by $84 \mathrm{~h}$ & BCS, days, ${ }^{1}$ and parity & None $^{2}$ \\
\hline $\mathrm{PR}^{4}$ at $35 \mathrm{~d}$ & Days, ${ }^{1}$ parity, and treatment & None $^{2}$ \\
\hline $\begin{array}{l}\text { PR } 35 \text { d after breeding } \\
\text { season }\end{array}$ & Days, ${ }^{1}$ parity, and treatment & $\begin{array}{l}\text { Days } \times \\
\text { parity }\end{array}$ \\
\hline Pregnancy loss & $\begin{array}{l}\text { BCS, days, }{ }^{1} \text { parity, } \\
\text { and treatment }\end{array}$ & None $^{2}$ \\
\hline
\end{tabular}

season did not differ among treatments $(P=0.89)$ and was not affected $(P \geq 0.14)$ by BCS, days postpartum, or parity.

\section{Occurrence of Estrus}

Activated estrus-detection patches were observed in $61.3 \%(758 / 1,236)$ of cows at $65 \mathrm{~h}$ after insert removal. Of the remaining cows, $42.2 \%(200 / 474)$ had activated estrus-detection patches at $84 \mathrm{~h}$, indicating estrus had occurred between 65 and 84 h. In total, $77.5 \%(958 / 1,236)$ of cows were observed with activated estrus-detection patches by $84 \mathrm{~h}$.

The proportion of cows expressing estrus by $65 \mathrm{~h}$ was not impacted $(P>0.10)$ by BCS, parity, days postpartum (Table 3), or their respective interactions. Likewise, the proportion of cows expressing estrus during the interval from 65 to $84 \mathrm{~h}$ was not influenced $(P>0.10)$ by BCS, parity, days postpartum, or their respective interactions. A greater proportion of cows $>82 \mathrm{~d}$ postpartum tended $(P=0.09)$ to express estrus by 84 h compared with cows $\leq 82 \mathrm{~d}$ postpartum $(79.8$ vs. $75.5 \%$, respectively).

Estrus-cycle status based on concentrations of progesterone was examined for its effect on occurrence of estrus in the subset of 427 cows for which that information was available. Analysis of the impact of estrus-cycle status on estrus expression revealed that similar $(P>0.26)$ proportions of cycling and anestrous cows were detected in estrus in each of the 3 observation periods ( 51 vs. $58 \%$ by 65 h, 25 vs. $28 \%$ between 65 and 84 h, and 65 vs. $70 \%$ by 84 h) for cycling and anestrous cows, respectively. The proportion of cows that had resumed estrous cycles $(32.3 \%$; 138/427) was influenced by neither BCS nor days postpartum. Primiparous cows, however, were more $(P<0.01)$ likely to be anestrous than their multiparous herd mates ( 94.6 vs. $63.6 \%$, respectively). 


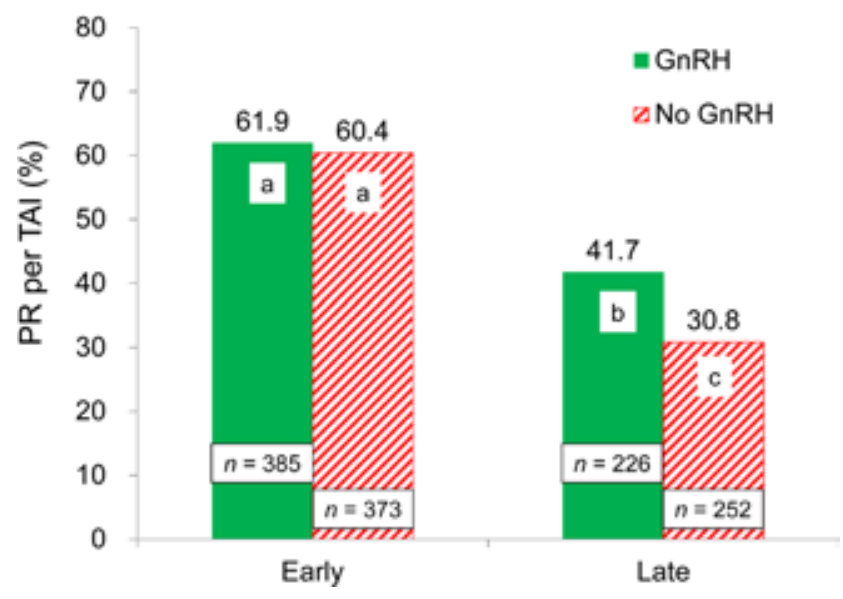

Figure 2. Pregnancy risk (PR) per timed AI (TAI) by treatment. The early cows were detected in estrus by $65 \mathrm{~h}$, inseminated, and either received $\mathrm{GnRH}$ at $65 \mathrm{~h}(\mathrm{E}+\mathrm{G})$ or did not receive $\mathrm{GnRH}(\mathrm{E}-\mathrm{G})$. The remaining cows were allocated to 2 late treatments: 1) injected with $\mathrm{GnRH}$ at 65 $\mathrm{h}$ and inseminated at $84 \mathrm{~h}(\mathrm{~L}+\mathrm{G})$ or 2$)$ no $\mathrm{GnRH}$ at $65 \mathrm{~h}$ and inseminated at $84 \mathrm{~h}(\mathrm{~L}-\mathrm{G}) .{ }^{\mathrm{a}-\mathrm{c}}$ Bars with different letters differ $(P<0.05)$. Values at the base of each bar represent the number of cows per treatment.

\section{DISCUSSION}

The current experiment demonstrates that $\mathrm{GnRH}$ is not essential to achieve acceptable PR $(>60 \%)$ when cows had expressed estrus before AI at $65 \mathrm{~h}$. More importantly, for cows not detected in estrus by $65 \mathrm{~h}$, treatment with GnRH at $65 \mathrm{~h}$ was beneficial only to enhance PR in cows that did not express estrus by $84 \mathrm{~h}$ when they were inseminated. Treating nonestrual cows at $65 \mathrm{~h}$ after $\mathrm{PGF}_{2 \alpha}$ with GnRH resulted in more than a 2-fold greater PR compared with non-GnRH-treated contemporaries inseminated at $84 \mathrm{~h}$. Cows observed in estrus by $65 \mathrm{~h}$ likely would have been exposed to an endogenous $\mathrm{GnRH}$-induced $\mathrm{LH}$ surge and subsequently spontaneously ovulated $31 \pm 0.6 \mathrm{~h}$ after the onset of estrus (White et al., 2002).

Programs that use 2 insemination times determined by occurrence of estrus allow for a closer alignment of the spontaneous LH surge, AI, and subsequent ovulation, negating the need for exogenous GnRH in cows that display estrus. Furthermore, use of estrus-detection patches to identify estrus accurately seems to be validated by the PR achieved ( $>60 \%)$ in cows not exposed to exogenous GnRH before TAI, regardless of time of AI.

In nonlactating beef cows that spontaneously display estrus, ovulation occurs $31 \mathrm{~h}$ after the initiation of estrus (White et al., 2002). Administering GnRH near the onset of estrus may induce the LH surge or augment the magnitude of the LH surge from the pituitary (Lucy and Stevenson, 1986); however, circulating concentrations of LH are only minimally influenced by exogenous $\mathrm{GnRH}$ after the spontaneous LH surge in dairy cows (Lucy and Stevenson, 1986; Pulley et al., 2015). In a previous experiment conducted in beef cows that were detected in estrus, no increase was detected in the proportion of

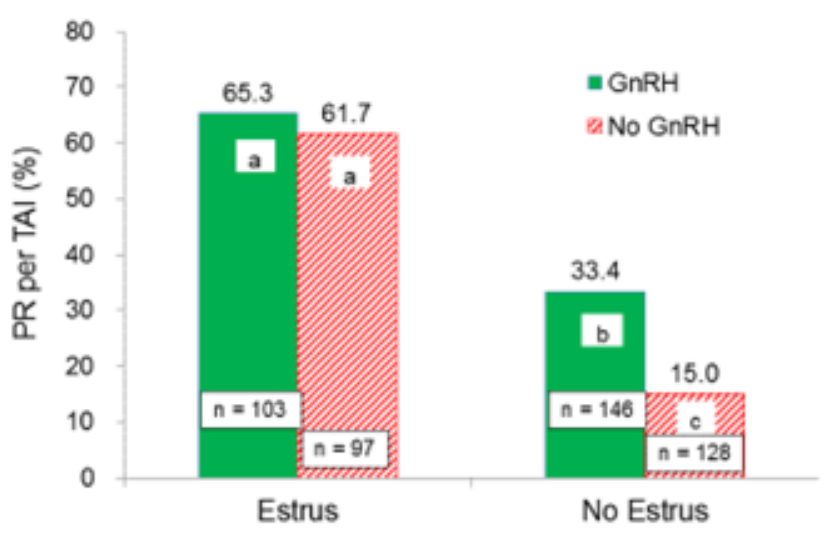

Figure 3. Pregnancy risk (PR) per timed AI (TAI) for cows inseminated at $84 \mathrm{~h}$. Based on whether the estrus-detection patch with $>50 \%$ activated between 65 and $84 \mathrm{~h}$ after controlled internal drug release insert removal, cows were classified as estrus or no estrus. ${ }^{\mathrm{a}-\mathrm{c}}$ Bars with different letters $\operatorname{differ}(P<$ $0.05)$. Values at the base of each bar represent the number of cows per bar.

cows becoming pregnant after AI when GnRH was administered at the time of AI (Perry and Perry, 2009). In that study, cows were subjected to AI between 6 and 18 $\mathrm{h}$ after estrus was first detected. In a TAI program, the interval from initiation of estrus until AI is variable, which may change the effectiveness of a GnRH injection concurrent with AI. Cows that ovulate after AI in a TAI program, and therefore have the opportunity to conceive, can be grouped into the classifications of those that spontaneously ovulate and those that are induced to ovulate after exogenous GnRH-induced LH release. Timing of the $\mathrm{GnRH}$ treatment in relationship to AI in cows that do not display estrus should be examined more closely. In the current study, cows that were detected in estrus before either the first $(65 \mathrm{~h})$ or the second $(84 \mathrm{~h})$ splittime AI had no improvement in PR after split TAI when treated with GnRH compared with untreated herd mates.

In split TAI programs, cows are treated differently based on the occurrence of estrus (Thomas et al., 2014a). The current study and previous research indicates that more than $50 \%$ of cows in a split TAI program displayed estrus by 60 to $65 \mathrm{~h}$ (Thomas et al., 2014b; Hill et al., 2016). In previous research (Hill et al., 2016), time to the first assessment of estrus was $60 \mathrm{~h}$ after CIDR insert removal, resulting in $46.3 \%$ of cows in estrus compared with $61.3 \%$ of cows detected by $65 \mathrm{~h}$ in the current study. Furthermore, for cows not detected in estrus by $60 \mathrm{~h}$ in the latter study, administration of $\mathrm{GnRH}$ at either $60 \mathrm{~h}$ ( $15 \mathrm{~h}$ before AI) or $75 \mathrm{~h}$ (concurrent with $\mathrm{AI}$ ) produced a similar PR. For cows not detected in estrus between 60 and $75 \mathrm{~h}$ in the latter study, PR did not differ but was numerically greater at $46 \%(n=139)$ compared with $39.1 \%(n=133)$ when $\mathrm{GnRH}$ was administered at $60 \mathrm{~h}$ vs. at $75 \mathrm{~h}$, respectively, and AI occurred at $75 \mathrm{~h}$. An earlier time of the first split-time AI will likely result in a smaller proportion of cows in estrus and more cows requiring GnRH before 
Table 3. Estrus expression by $65 \mathrm{~h}$, between 65 and $84 \mathrm{~h}$, and by $84 \mathrm{~h}$ after controlled internal drug release insert removal as affected by BCS, parity, days postpartum, and GnRH

\begin{tabular}{|c|c|c|c|c|c|c|}
\hline \multirow[b]{2}{*}{ Item } & \multicolumn{2}{|c|}{$\begin{array}{l}\text { Estrus by } \\
65 \mathrm{~h}\end{array}$} & \multicolumn{2}{|c|}{$\begin{array}{c}\text { Estrus between } \\
65 \text { and } 84 \mathrm{~h}\end{array}$} & \multicolumn{2}{|c|}{$\begin{array}{l}\text { Estrus by } \\
84 \mathrm{~h}\end{array}$} \\
\hline & $n$ & $\%$ & $n$ & $\%$ & $n$ & $\%$ \\
\hline \multicolumn{7}{|l|}{ Days postpartum } \\
\hline$\leq 82$ & 596 & 61.1 & 229 & 37.9 & 596 & $75.5^{\mathrm{a}}$ \\
\hline$>82$ & 640 & 65.8 & 245 & 41.6 & 640 & $79.8^{\mathrm{b}}$ \\
\hline \multicolumn{7}{|l|}{ BCS } \\
\hline$\geq 5$ & 689 & 64.3 & 269 & 41.8 & 689 & 79.3 \\
\hline$<5$ & 547 & 62.6 & 205 & 37.7 & 547 & 76.1 \\
\hline \multicolumn{7}{|l|}{ Parity } \\
\hline Primiparous & 287 & 64.2 & 119 & 37.5 & 287 & 77.1 \\
\hline Multiparous & 949 & 62.7 & 355 & 42.0 & 949 & 78.4 \\
\hline $\mathrm{GnRH}$ at $65 \mathrm{~h}$ & - & - & 249 & 40.9 & - & - \\
\hline No GnRH at $65 \mathrm{~h}$ & - & - & 225 & 38.6 & - & - \\
\hline
\end{tabular}

a,b Means within estrus category with different superscript letters tend $(P<0.10)$ to differ.

the second split-time AI. Therefore, timing of estrus may be important relative to the selected first and second split time, so further examination of insemination timing in a split TAI program is warranted.

The initial studies using the Ovsynch and CO-Synch programs in beef cattle demonstrated the importance of inducing ovulation by administering GnRH either before or concurrently with insemination in a 7-d TAI program (Geary and Whittier, 1998). Interval from PGF $_{2 \alpha}$ injection to spontaneous ovulation in TAI systems varies depending on the prior estrus-cycle status, parity, and the stage of the estrous cycle at the initiation of the procedure (Geary et al., 2000). Results of the current experiment indicate that the increase in PR from GnRH treatment was associated with cows that did not display estrus.

Previous studies have identified conditions that alter the proportion of cows that display estrus at a given time or in total. Postpartum suckled cows that are anestrous at the onset of TAI programs seem to display estrus earlier than their estrus-cycling herd mates (Geary et al., 2000; Stevenson et al., 2000; Busch et al., 2008). In contrast, previous estrus cycle status of the sampled subpopulation of cows in the present study did not influence the proportion of cycling and noncycling cows detected in estrus by $65 \mathrm{~h}$ after $\mathrm{PGF}_{2 \alpha}$. Cows with a lesser BCS, however, are less likely to display estrus than cows with a greater BCS (Richardson et al., 2016). Stage of the estrous cycle at the initiation of the synchronization program for cycling heifers can alter the timing of estrus (Atkins et al., 2008). Furthermore, variations in the response to GnRH have been identified in beef cows depending on the stage of their follicular wave and their prior estrus cycle status (Atkins et al., 2010a,b). In our previous research (Hill et al., 2016), we noted that more primiparous cows with BCS $>5$ were in estrus by $60 \mathrm{~h}$ after $\mathrm{PGF}_{2 \alpha}$ than older and thinner cows. In contrast, in the current study, occurrence of estrus by $65 \mathrm{~h}$ after the removal of the CIDR insert was not affected by parity, BCS, or cycling status. It is possible that the different time after CIDR insert removal chosen to measure estrus masked some of these physiological causative factors. In our previous report (Hill et al., 2016), time to the first assessment of estrus was $60 \mathrm{~h}$ after CIDR insert removal, resulting in $46.3 \%$ of cows in estrus compared with $61.3 \%$ of cows detected by $65 \mathrm{~h}$ in the current study.

In summary, GnRH injection at AI improved PR only in those cows that were not detected in estrus before time of AI. Cows that exhibited estrus, regardless of GnRH treatment, had better PR than cows that did not display estrus. Insemination at a predetermined time in beef cows can reduce the time and labor associated with conventional single standard fixed-time AI program. The split-time AI program serves as a compromise between conventional AI after detection of estrus and a standard one fixed-time AI program. Depending on the cost of GnRH (range of US\$2.22 to $\$ 3.10$ per dose) and $60 \%$ of cows in estrus by $65 \mathrm{~h}$, the economic trade-off of using estrus-detection patches in a splittime AI program is favorable and saved $\$ 0.33$ to $\$ 0.86$ per cow but does not account for the extra time and cow-calf handling invested to carry out the second AI at $84 \mathrm{~h}$. Furthermore, the cost of semen and sire selection for cows detected in estrus having resulting greater PR compared with those not detected in estrus having lesser PR could provide other favorable options and economic advantages for using a split-time AI program.

\section{LITERATURE CITED}

Atkins, J. A., D. C. Busch, J. F. Bader, D. H. Keisler, D. J. Patterson, M. C. Lucy, and M. F. Smith. 2008. Gonadotropin-releasing hormone-induced ovulation and luteinizing hormone release in beef heifers: Effect of day of the cycle. J. Anim. Sci. 86:83-93. doi:10.2527/jas.2007-0277

Atkins, J. A., M. F. Smith, K. J. Wells, and T. W. Geary. 2010a. Factors affecting preovulatory follicle diameter and ovulation rate after gonadotropin-releasing hormone in postpartum beef cows. Part I: Cycling cows. J. Anim. Sci. 88:2300-2310. doi:10.2527/ jas.2009-2531

Atkins, J. A., M. F. Smith, K. J. Wells, and T. W. Geary. 2010b. Factors affecting preovulatory follicle diameter and ovulation rate after gonadotropin-releasing hormone in postpartum beef cows. Part II: Anestrous cows. J. Anim. Sci. 88:2311-2320. doi:10.2527/ jas.2009-2532

Bellows, R. A., R. E. Short, and G. V. Richardson. 1982. Effects of sire, age of dam and gestation feed level on dystocia and postpartum reproduction. J. Anim. Sci. 55:18-27. 
Busch, D. C., D. J. Schafer, D. J. Wilson, D. A. Mallory, N. R. Leitman, J. K. Haden, M. R. Ellersieck, M. F. Smith, and D. J. Patterson. 2008. Timing of artificial insemination in postpartum beef cows following administration of the CO-Synch + controlled internal drug release protocol. J. Anim. Sci. 86:1519-1525. doi:10.2527/ jas.2008-0925

Geary, T. W., E. R. Downing, J. E. Bruemmer, and J. C. Whittier. 2000. Ovarian and estrous response of suckled beef cows to the Select Synch estrous synchronization protocol. Prof. Anim. Sci. 16:1-5.

Geary, T. W., and J. C. Whittier. 1998. Effects of a timed insemination following synchronization of ovulation using the Ovsynch or CO-Synch protocol in beef cows. Prof. Anim. Sci. 14:217-220.

Hill, S. L., D. M. Grieger, K. C. Olson, J. R. Jaeger, C. R. Dahlen, G. A. Bridges, F. Dantas, J. E. Larson, A. M. Muth-Spurlock, J. K. Ahola, M. C. Fischer, G. A. Perry, E. L. Larimore, T. L. Steckler, W. D. Whittier, J. F. Currin, and J. S. Stevenson. 2016. Using estrus-detection patches to optimally time insemination improved pregnancy risk in suckled beef cows in a fixed-time artificial insemination program. J. Anim. Sci. doi:10.2527/jas2016-0469.

Ireland, J. J., R. L. Murphee, and P. B. Coulson. 1980. Accuracy of predicting stages of bovine estrous cycle by gross appearance of the corpus luteum. J. Dairy Sci. 63:155-160. doi:10.3168/jds. S0022-0302(80)82901-8

Johnson, S. K., R. N. Funston, J. B. Hall, D. J. Kesler, G. C. Lamb, J. W. Lauderdale, D. J. Patterson, G. A. Perry, and D. R. Strohbehn. 2011. Multi-state Beef Reproduction Task Force provides science-based recommendations for the application of reproductive technologies. J. Anim. Sci. 89:2950-2954. doi:10.2527/ jas.2010-3719

Lucy, M. C., and J. S. Stevenson. 1986. Gonadotropin-releasing hormone at estrus: Luteinizing hormone, estradiol, and progesterone during the periestrual and postinsemination periods in dairy cattle. Biol. Reprod. 35:300-311. doi:10.1095/biolre$\operatorname{prod} 35.2 .300$

Markwood, M. G., R. K. Peel, J. K. Ahola, G. E. Seidel Jr., R. N. Funston, S. L. Lake, and J. C. Whittier. 2014. Effect of delaying time AI based on ESTROTECT ${ }^{\mathrm{TM}}$ patch status on pregnancy rates of nursing beef cows. Proc. - Am. Soc. Anim. Sci., West. Sect. 65:79-82.
Perry, G. A., and B. L. Perry. 2009. GnRH treatment at artificial insemination in beef cattle fails to increase plasma progesterone concentrations or pregnancy rates. Theriogenology 71:775-779. doi:10.1016/j.theriogenology.2008.09.050

Pulley, S. L., D. H. Keisler, and J. S. Stevenson. 2015. Concentrations of luteinizing hormone and ovulatory responses in dairy cows before timed artificial insemination. J. Dairy Sci. 98:6188-6201. doi:10.3168/jds.2015-9473

Richardson, B. N., S. L. Hill, J. S. Stevenson, G. D. Gemechis, and G. A. Perry. 2016. Expression of estrus before fixed-time AI affects conception rates and factors that impact expression of estrus and the repeatability of expression of estrus in sequential breeding seasons. Anim. Reprod. Sci. 166:133-140. doi:10.1016/j.anireprosci.2016.01.013

Stevenson, J. S., K. E. Thompson, W. L. Forbes, G. C. Lamb, D. G. Grieger, and L. R. Corah. 2000. Synchronizing estrus and (or) ovulation in beef cows after combinations of $\mathrm{GnRH}$, norgestomet, and prostaglandin $\mathrm{F}_{2 \alpha}$ with or without timed insemination. J. Anim. Sci. 78:1747-1758.

Thomas, J. M., S. L. Lock, S. E. Poock, M. R. Ellersieck, M. F. Smith, and D. J. Patterson. 2014a. Delayed insemination of nonestrous cows improves pregnancy rates when using sex-sorted semen in timed artificial insemination of suckled beef cows. J. Anim. Sci. 92:1747-1752. doi:10.2527/jas.2013-7131

Thomas, J. M., S. E. Poock, M. R. Ellersieck, M. F. Smith, and D. J. Patterson. 2014b. Delayed insemination on non-estrous heifers and cows when using conventional semen in artificial insemination. J. Anim. Sci. 92:4189-4197. doi:10.2527/ jas.2014-7827

White, F. J., R. P. Wettemann, M. L. Looper, T. M. Prado, and G. L. Morgan. 2002. Seasonal effects on estrous behavior and time of ovulation in nonlactating beef cows. J. Anim. Sci. 80:3053-3059.

Wiltbank, M.C., and J.R. Pursley. 2014. The cow as an induced ovulator: Timed AI after synchronization of ovulation. Theriogenology 81:170-185. doi:10.1016/j.theriogenology.2013.09.017 